\title{
The Music of Brazil in the Eyes of Anglo-American Academic Literature
}

\section{"Para inglês ouvir": a música do Brasil na literatura acadêmica anglo-americana}

\author{
Silvano Baia \\ Universidade Federal de Uberlândia, Minas Gerais, Brazil \\ silvanobaia@gmail.com
}

\begin{abstract}
This paper presents an analysis of the literature on Brazilian music written in English and developed by Anglo-American researchers. Based on a critical reading of texts published in books dedicated to Brazilian music, it identifies prevalent themes and approaches in such circuits, as well as indicating recurring concepts and trends that underpin the discourses present in such texts. From this overview, interpretations emerge on the country's musicality and on how Brazil is seen by means of the study of their music. Besides a valorization of certain approaches and part of the musical production - popular music and some specific genres - many social, political and cultural conceptions surface in this context in which there is a circulation of ideas about a Brazil written in English.
\end{abstract}

Keywords: Music of Brazil; Brazilian popular music; Brazilian Studies; History of Brazilian music.

Resumo: Este artigo apresenta uma análise da literatura sobre a música do Brasil escrita em inglês e desenvolvida por pesquisadores anglo-americanos. A partir de uma leitura crítica de textos publicados em livros dedicados à música brasileira, localizam-se as temáticas e abordagens predominantes em tal circuito, assim como se apontam conceitos e tendências recorrentes que sustentam os discursos presentes em tais textos. Desse panorama, resultam interpretações acerca da musicalidade do país e de como este é pensado através dos estudos da sua música. Além de uma valorização de certa abordagem e de uma parcela da produção musical - a música popular e alguns gêneros específicos -, muitas concepções culturais, políticas e sociais emergem nesse contexto em que circulam ideias sobre um Brasil escrito em língua inglesa.

Palavras-chave: Música do Brasil; Música popular brasileira; Estudos brasileiros; História da música brasileira.

Submission date: 25 January 2017

Final approval date: 14 April 2018

\section{1 - Introduction}

Music occupies a special place in Brazilian culture, highlighting the musical production that was conventionally named popular music. Consequently, there is a vast and growing production of studies in various fields of knowledge whose subject is Brazilian music, especially popular music. With considerable international repercussion, Brazilian music has also attracted the attention of foreign researchers - mainly in English-speaking countries - whose studies have grown significantly in recent years. However, researches carried out overseas still have a relatively restricted circulation in Brazil; they are not fully embedded in the field of studies as a literature with which one must engage. 
Certainly, the external view of researchers qualified in another culture has much to contribute to the knowledge of Brazilian music. Such a detachment tends to provide observations not guided by the dynamics and internal agendas of studies in Brazil, the entrenched ideas about the country's culture nor by positions or even direct engagement in political struggles. Whereas the question of being "national" has always been one of the central problems posed for Brazilian culture in general, and musicology in particular, we can speculate that nationalist positions linked to discourses of "authenticity", "root" and "tradition" can lead to the disregard of foreign views. However, these views can offer a significant contribution precisely because in theory, they tend not to be directly driven by aesthetic, poetic and ideological struggles in the field of music studies in the country.

This article presents an overview of the books on Brazilian music written by English-speaking researchers in order to analyse the thought that has been developing abroad, especially in the United States and the United Kingdom. It will take into account works of scholars who have English as their mother tongue. Authors from Brazil who have production in English and who live and teach abroad or Brazilian texts translated and published in English, will not be included herein. The proposal was to develop a critical analysis of the production, which leads to a heuristic reading of a selected corpus. Although the literature in English comprises a bibliography in books, articles in journals or collections, theses and presentations at conferences, this article focuses only on books fully dedicated to Brazilian music; the idea is that, in general, books present more deepened and consolidated researches, many of which were developed as doctoral theses. A corpus of 30 books, all listed in the references, were analysed.

\section{2 - Pioneers of Brazilian music studies abroad}

There are some sparse articles on Brazilian music published in English before 1960 (GATES, 1939; HERSKOVITS, 1946), but the development of a more consistent research begins in the second half of that decade with the works of Gerard BÉHAGUE. ${ }^{1}$ As a recognized forerunner in this field, he dedicated his doctoral thesis, Popular musical currents in the art music of the early nationalistic period in Brazil, ca. 1870-1920 (1966) to an historical research of Brazilian music; his further studies contemplated various sonorities, including the urban popular music. Throughout his career, he contributed to the study of Brazilian and Latin American music, with special attention to African influences, and is considered one of the founders of a Latin American ethnomusicology. His discovery of the manuscripts of Biblioteca da Ajuda, Portugal, (1968) was a major contribution to Brazilian musicology, as well as the invaluable entries he wrote for the New Grove Dictionary of Music and Musicians (SADIE; TYRRELL, 2001), which comprises most of what is written about Brazil in this publication. Among the pioneers, we can also mention Robert STEVENSON2, whose article Some Portuguese sources for early Brazilian music history (1968) is still a quoted reference.

1 Gerard Béhague (1937-2005), ethnomusicologist, born in France, studied and lived in Brazil and developed his academic career in the United States. For more information than presented in this article, see: VOLPE, Maria Alice. O legado de Gerard Béhague (1937-2005). Revista Brasileira de Música, v. 23/1, 2010.

2 Robert Stevenson (1916-2012), American sociologist, was a professor at the University of California, Los Angeles (UCLA). 
During the 1980s, a line of studies emerges in a non-organized group of researchers dedicated to the popular music of Brazil. The works of Charles PERRONE ${ }^{3}$ were precursors in this regard and his writings inspired other researchers. The object was embraced hereafter by academics in the United Kingdom and the United States, like David TREECE ${ }^{4}$ and Brian MCCANN ${ }^{5}$, respectively, and also by writers of a more journalistic approach such as McGOWAN and PESSANHA. ${ }^{6}$ By 2000, this production begins to increase in the number of book titles, although some are publications of doctoral theses defended in the 1990s. Such publications are added to works of Brazilian scholars who live and work abroad, like Cristina Magaldi, ${ }^{7}$ Idelber Avelar, ${ }^{8}$ Suzel Reily ${ }^{9}$ and Welson Tremura ${ }^{10}$, as well as translations and publications of Brazilian authors who reside in Brazil. However, only a lesser amount of what is produced in Brazil is published in English.

This literature written in English is already a significant body of works and plays a key role in the dissemination and knowledge of Brazilian music abroad, given the limitations of the Portuguese language in the international arena. Brazilian researchers should be familiar with such studies, because they present original elaborations and highlight aspects sometimes disregarded. Naturally, these works do not form a homogeneous body in terms of quality and relevance, yet they feature distinct themes and approaches, which are incompatible at times. Assuming we want to engage with the ideas that circulate in the world about Brazilian music, it is essential to know the concepts already established.

\section{3 - Popular music as the music of Brazil}

Considering the 30 books listed in this survey, only six of them, by five different authors, are aimed directly to the study of classical music, four of which deal with the most renowned Brazilian composer: Villa-Lobos (WRIGHT, 1992), Heitor Villa-Lobos: the search for Brazil's musical soul (BÉHAGUE, 1994), Heitor Villa-Lobos: a life (1887-1959) (APPLEBY, 2002) and Villa-Lobos: the music - an analysis of his style (PEPPERCORN, 2005). Still, in the classical music field, we have Camargo Guarnieri: Brazilian composer (VERHAALEN, 2005) and an historical study, The music of Brazil (APPLEBY, 1983), which we shall observe in detail later. The other books are directed either to the various genres of popular music or to the study of African influences in our musical culture, although some of these titles make brief incursions on themes

3 Charles Perrone is professor at the Department of Spanish and Portuguese Studies, University of Florida, USA.

4 David Treece is a professor at King's College London. Scholar on music, literature and Brazilian culture, he has articles and books on the subject, among which Exilados, aliados, rebeldes: o movimento indianista, a política indigenista e o Estado-nação imperial (2008).

5 Brian McCann is professor at Georgetown University, Washington, DC, at History department.

6 Chris McGowan (American) and Ricardo Pessanha (Brazilian) are journalists.

7 Cristina Magaldi is professor at Music Department of Towson University, Maryland, USA.

8 Idelber Avelar is professor at Tulane University, New Orleans, Louisiana, USA, at Spanish \& Portuguese Department.

9 Suzel Ana Reily, ethnomusicologist, worked for a long period at Queen's University Belfast, Northern Ireland, UK. Nowadays she is professor at Universidade Estadual de Campinas, Brazil.

10 Welson Tremura, ethnomusicologist, is professor at the University of Florida, USA, at College of the Arts. 
related to classical music. In this regard, we highlight GARCIA/LIVINGSTON-ISENHOUR (2005), Choro: a social history of the Brazilian popular music, and GALM (2010), The berimbau: soul of Brazilian music. Both authors devote a chapter to the presence and the repercussions of their respective objects in the erudite field; however, in such cases, the proposals of research favoured this inclusive approach.

The first conclusion that stands out when we analyse the material is that the privileged object of these studies is popular music. At first glance, this may seem an obvious, predictable thing, though it is not as simple as that. We are referring to academic papers, which are texts produced by scholars of music and culture, many of which seek, through music, to study and discuss the Brazilian society. The fact that popular music has attracted the interest of the aforementioned researchers is something that deserves reflection.

Clearly, many of these texts aim to observe Brazilian culture and aspects of the country's social, political and cultural background through music. In Brazil, popular music offers more elements to this type of analysis. However, this also reinforces its importance in Brazilian culture. If a similar study were to be done on German or Austrian music, for example, this balance would certainly be different. Popular music - particularly genres such as bossa nova, samba, MPB, and recently, those which are more contemporary, such as mangue beat and axé music - is the music of Brazil which is known abroad, whether we like it or not. For those who are aware of this information - a more educated public interested in music from other cultures - Brazilian popular music is considered to be artistically refined and of high quality. In amongst winding paths and subtle irony of history, it came to accomplish the project of Mario de Andrade and musical nationalism, which consisted of building a genuinely national artistic music style (BAIA, 2015). Clearly, this limited repercussion of classical music in these studies is only one indicator. An assessment of the current status of our concert music abroad would have to include other key data such as recordings, performances and score editions of national composers. It indicated a reflection - which will not be developed in this text - about why Brazilian classical music, with the exception of very few composers, particularly Villa-Lobos, did not achieve the same international repercussion of popular music and where this production in the contemporary music scene is located. Likewise, the displacement and circulation of such music - originally considered popular - in erudite circles of other countries, reaffirms the fragility and lack of elements to keep the division of the musical field in Brazil between "popular" and "erudite".

\section{4 - Recurrent thematics}

Although there is a diversification regarding the specific objects of research, some themes prevail, particularly concerning the musical genres in focus, where there is an emphasis on those that have samba as its central axis. Another significant line of study refers to identity issues and aspects of the country's ethnic background, with special attention on African influences in Brazilian culture and the integration of black people in our society. The composition and ethnic mixtures that contributed to form what is meant by "Brazilianness" is an omnipresent matter in the study of Brazilian culture.

Among the musical genres examined, there is a predominance of those associated with the canonical narrative of the history of Brazilian popular music that has samba from Rio de Janeiro 
as its core; from this narrative, the samba-bossa-MPB-tropicália lineage emerges as an articulator of how the tradition of Brazilian popular music has been understood. The following studies of these genres present different views and approaches and some are even dedicated to critical reflection on the traditional narrative: Masters of contemporary Brazilian songs: MPB 1965-1985 (PERRONE, 1989), The Brazilian sound: samba, bossa nova and popular music of Brazil (McGOWAN/PESSANHA, 1991), The social history of Brazilian samba (SHAW, 1999), Brutality garden: Tropicália and the emergence of a Brazilian counterculture (DUNN, 2001), Hello, hello Brazil: popular music in the making of modern Brazil (McCANN, 2004), Brazilian popular music: Caetano Veloso and the regeneration of tradition (LEU, 2006), The defence of tradition in Brazilian popular music: politics, culture and the creation of Música Popular Brasileira (STROUD, 2008), Brazilian jive: from samba to rap (TREECE, 2013), Making samba: a new history of race and music in Brazil (HERTZMAN, 2013). Here, it is also worthy to mention Samba: resistance in motion (BROWNING, 1995), a research on the field of Dance with connections to Music. There also exists a book dedicated to choro, a genre which, although being part of the narrative of the tradition of Brazilian music founded in the music of Rio, constitutes a particular case: Choro: a social history of the Brazilian popular music (GARCIA / LivingstonISENHOUR, 2005).

On the prevalence of these genres, firstly it should be known that throughout history, they are the ones which have been associated with issues of national identity, a theme dear to researchers who study Brazilian music from another culture. Other genres - such as frevo, maracatu, baião, the caipira/sertanejo or the music from Rio Grande do Sul or Pará - have been characterised more as regional music, either under historical circumstances or because they are associated, in different degrees of consciousness, to certain regional identities (MURPHY, 2006). In addition to this affinity with the debates on national identity, this musical lineage developed around the samba offers several elements for reflection about African influences in music and in Brazilian culture, another issue highlighted in the agenda of studies in the AngloAmerican academia. It should be noted that many texts have critical reviews of the traditional narratives around these genres, as can be seen in the works of David TREECE (2013), Sean STROUD (2008) and Mark HERTZMAN (2013), in different perspectives and interpretative lines.

The dynamics of the development of researches is something that should also be considered. It is natural that studies have begun with the most established genres and in dialogue with the more traditional narratives. It was so, in Brazil, as from the 1970s, when a field of popular music studies came to be, whose researches were highly concentrated on the samba-bossa-MPBtropicália lineage (BAIA, 2014). Over time, a critical review of this restrictive trend was established and today the investigations cover genres previously ignored, which can also be identified in researches carried out abroad. From this point of view, a fundamental reference is Masters of contemporary Brazilian songs: MPB 1965-1985, by Charles PERRONE (1989). As the first academic study published in English as a book, it presented an object of study and paved the way for other researchers. The book analyses the work of the central names of MPB at the moment it was written, and the production of such names offer elements for literary studies: Chico Buarque, Caetano Veloso, Gilberto Gil, Milton Nascimento and the duet João Bosco and Aldir Blanc. The text was attuned to the researches on popular music that were being developed in Brazil, which were strongly boosted during the 1970s and 1980s with the methodology developed in the field of Languages and Literature (Letras) based on the discourse analysis of 
the lyrics of the songs from which sociological discussions were derived. Although the authors were concerned about the context of the songs analysed and intended - albeit in an incipient manner - to contemplate sonorous aspects, the centre of the studies was the literary text. In that sense, the book shared the methodological problems that were posed to the researchers in Brazil at that stage of knowledge at that time.

In the latest researches, we can identify the appropriation of the theoretical tools developed to approach the song in the field of popular music studies in recent decades, like in Brazilian jive, by David TREECE. Launched in 2013, his book presents an analysis of the Brazilian musicality developed around a set of core genres in popular music of Brazil, especially samba, bossa nova and rap. Treece emphasises that these genres cannot be fully understood without the perception of their character as a song; all these musical practices should be thought of in their interactions between musical elements and literary texts, as well as according to the sociohistorical context. For the author, in many Brazilian popular musical genres, especially samba, bossa nova and rap, there would be a cultural and philosophical foundation from African origin. The thought that Treece develops about these genres - on what they meant and mean in Brazilian musical practices, their symbolic representations and their changes over time - is articulated around a common element of continuity of Afro-Brazilian traditions, to a certain degree of integration or friction with other components of the country's culture, especially the European heritage.

As it occurred in Brazilian researches, over time, other musical genres and more contemporary sounds were incorporated. Taken together, these studies began to reflect the diversity of the country's musicality in a more balanced way. An example in this direction is Contemporary carioca: technologies of mixing in a Brazilian music scene (MOEHN, 2012). The object of study is the musical scene in a middle-class neighbourhood in Rio de Janeiro during the 1990s, highlighting the works of Marcos Suzano, Lenine, Pedro Luiz e a Parede, Fernanda Abreu and Paulinho Moska, musicians who blended bossa nova, traditional samba and other Brazilian genres - particularly those coming from the Northeast of Brazil - with rock, hip hop and funk.

Other books that could be lined up in this trend of looking into other genres are: Brazilian music: maracatu atomico: tradition, modernity, and postmodernity in the Mangue movement and the "new music scene" of Recife, Pernambuco, Brazil (GALINSKY, 2002), Let's make some noise: axé and the African roots of Brazilian popular music (HENRY, 2008) e Ideologies of marginality in Brazilian hip hop: retelling marginality through music (PARDUE, 2008), Northeastern traditions and the heartbeat of a modern nation (CROOK, 2009) e River of tears: country music, memory and modernity in Brazil (DENT, 2009).

Some titles present more specific objects of research. Among these, there are two sets of articles by Brazilian and Anglo-American scholars: Brazilian popular music and citizenship (AVELAR; DUNN, 2011) e Brazilian popular music and globalization (DUNN; PERRONE, 2001). Eric GALM discusses Brazilian music by looking at a particular instrument: The berimbau: soul of Brazilian music (2010). According to the author, his book is "the first in-depth study to see music and Brazilian culture by berimbau lens". John BURDICK in The color of sound: race, religion and music (2013), studied the black identity in three groups who identify themselves as blacks, divided into three distinct gospel musical scenes - gospel rap, gospel samba and black gospel. This study was carried out through the analyses of the practices and speeches of musicians and 
performers. The author examined how specific practices of making music help generate collective identities, and also sought to situate the role of music in this formation of identity.

Whatever the musical genres under study may be, the approaches generally tend to focus discussions on Brazilian identity, highlighting the relationships and tensions between descendants of ethnic groups who participated in the social formation of the country. In several works mentioned herein, a prominent role is given to the interactions between music from Africa and Brazil and between their musicalities and ethnic tensions in the course of history. This is reflected in the use of the word "resistance" in three titles: Samba: resistance in motion (BROWNING, 1995), Rhythms of resistance: African musical heritage in Brazil (FRYER, 2000) and Domination and resistance in Afro-Brazilian music (SWANSON, 2015).

It is glaring that researches developed in the United States and the United Kingdom tend to prioritize sensitive issues for the agenda of Anglo-American studies. Thus, the question of the ethnic formation of Brazil and the place of black people in Brazilian society have great prominence in all studies herein, as well as "Brazilianess" as an identity, or even gender-related issues. Two authors and concepts associated with them are mentioned in almost all works in focus: Gilberto Freyre and the expression "racial democracy" - which usually appears as the "myth of racial democracy" and is supposedly linked to Freyre's ideas - and Oswald de Andrade's "cultural cannibalism". These topics are important indicators of the perception of the country abroad and deserve a long and complex debate that is beyond the scope of this article.

\section{5 - Relations (of this literature) to Brazilian Studies and to popular music studies made in Brazil}

Internationally, there is a field of studies on Brazilian issues, involving politics, society and culture, called Brazilian Studies. It started in the United States in the 1960s and nowadays there are departments and courses dedicated to Brazilian studies in universities in several countries, such as the Brazil Institute at King's College London. There is even a name - not universally accepted - for researchers in this field: Brazilianists. In Brazil, this term has a somewhat negative connotation that is distinct from its meaning in the Northern hemisphere, perhaps because it is associated to a certain ideological anti-Americanism, which is still present in some sectors of Brazilian society, although having lost strength recently. Albeit, not being a singularity, since other countries are objects of many studies too, the existence of this field indicates the importance of the country and the relevance of its culture. We can assume that these studies were motivated by geopolitical aspects after World War II, especially during the 1960s; but certainly the uniqueness of Brazilian culture contributed to the formation of this field of studies, and is, in this case, what best fits the musical studies.

The bibliography that this article analyses is associated with the field of study of popular music in Brazil, but constitutes a sector somewhat apart from the production developed in Brazil. It composes the same field, but its relations are mediated by traces of language and "place": the works in English dialogue especially with each other, and with texts by Brazilian authors published in English; works in Portuguese are cited (particularly those of more impact or that have been published in books), since these researchers generally speak Portuguese (some are highly proficient), but to a lesser extent and with different distribution from that in Brazil. 
Those not published in English or that have no significant part of their production translated into English are somewhat hindered in this debate, given the relative valuation of texts available in English. For example, José Miguel Wisnik, Luiz Tatit and Marcos Napolitano, although mentioned by some foreigners, do not have the same impact they have in Brazil; also, José Ramos Tinhorão is less mentioned than he is in researches carried out in the country. Hermano VIANNA is often cited, since his classic The Mystery of Samba (1995) was translated into English, with good effect; Carlos SANDRONI as well, although his Feitiço Decente (2001) has no English version. This distribution, however, can be nuanced by the academic fields; in the AngloAmerican literature, an anthropological approach overlaps the historical one. Thus, for example, in the case of the repercussion of Vianna's work, the fact that the study is directly linked to the issue of ethnic relations, so dear to the Anglo-American researchers, should be added to his merits.

\section{6 - Historical narratives and the lines of thought about music in Brazil}

As with the production developed in Brazil by Brazilian researchers, there are few books in this bibliography dedicated to a historical narrative of longue durée; most titles focus on specific periods or objects. Two books purport to be an overview: Music in Brazil: experiencing music, expressing culture, by John P. MURPHY (2006); and The music of Brazil, by David P. APPLEBY (1983), which is dedicated to the study of classical music.

Son of an American pastor, Appleby was born in Brazil and moved to the United States, where he developed his academic and professional life. His book presents a version of the traditional narrative on classical music in Brazil. It starts with the music in the colonial period - the music of the Portuguese, the native indians and Africans -, pinpointing the problem of sources for the knowledge of the music thereof. It underlines the role of the Portuguese Court present in Rio de Janeiro in the early 19th Century, and the impulse that it meant to the classical music practice. Then, it discusses the first nationalist compositions in Brazilian music and the persona of Carlos Gomes. A chapter is devoted to the relationship between folk, popular and classical music, as musicology discussed it at the time. In the topic that approaches nationalism and postnationalism, the narrative is centered around the most outstandingly canonical composers.

The book is still useful nowadays - yet it must have been more helpful at the time of its publication - as a reference in English for a first approach on a portion of Brazilian musical production which is little known abroad: hence the merit it holds. However, it shares the problems that comprehensive compendiums of music history and musicological texts usually had until around the beginning of the 1980s. For instance, it does not incorporate the methodology of History; with that, the narrative is developed as a chain of events, authors and musical works, without reflection on the interactions between the musical style and the sociohistorical context.

As in the tradition of Brazilian musicology, the modinha and lundu are contemplated in Appleby's narrative as the first musical genres that emerged here, as well as the popular urban music genres of the late 19th and early 20th Century in Rio de Janeiro, which provided "popular" references for the "school" of musical nationalism. Besides that, popular urban music 
is not part of the narrative. It is the counterpart of popular music studies, which is only concerned about popular music and looks into classical production only when it has to do with the world of "popular", like Villa-Lobos, Radames Gnatalli and Rogério Duprat. It is as if there were two histories of music in Brazil that run side-by-side, yet separately from each other.

Naturally, it needs to be considered, in the criticism of Appleby's book, which was written almost 30 years ago, that from then on, Brazilian musicological researches have developed, driven by post-graduate programs in the Music field. The very Musicology has changed thenceforth at an international level, once a reformulation has been carried out regarding the concepts and methodologies that used to be in the mainstream of the subject before. On the other hand, very few academic musicologists have ventured into writing a long-term history of music in Brazil. Among the few examples in the field of classical music, Bruno KIEFER's (1977) book is one which is worthy of mention, written to address the lack of teaching material at that moment, released a few years before Appleby's, which is more complete and probably would have been widely adopted in Brazil, as Kiefer's was, had it been translated into Portuguese.

Music in Brazil, by John P. MURPHY (2006), was written for the Global Music Series, a set of books on Ethnomusicology, published by Oxford University Press, focused on the music of specific countries or regions, which comprises 25 titles. The first one was Thinking musically (WADE, 2003), the central book in the series, which explores the musical diversity of the world's different cultures. Similarly to the subsequent titles of the series, it is subtitled Experiencing music, expressing culture and comes with a CD with the songs analysed or mentioned as examples throughout the text. This is a material to be used in the classroom; it contains information, cultural references and musical examples, hence its usefulness for an initial approach to such musical diversity.

It may be worthwhile comparing and tracing a parallel between Murphy's approach and Musiques du Brésil: de la cantoria a la samba-reggae (1999), by Gerard BÉHAGUE, also written in a similar format with kindred objectives. As a matter of fact, Murphy's book is dedicated to Béhague. Undoubtedly, it is a troublesome task to organize a presentation of the Brazilian musical diversity of genres and practices which - far from being watertight or featuring independent and autonomous aspects - these are rather intertwined and mutually influenced. Thus, we shall examine how Murphy and Béhague carried out this task, once these books have similar educational goals.

Murphy's text begins by saying that, although Brazilian music is diverse and ravishing, it is almost unknown around the world, with the exception of samba and bossa nova. Aiming to present it to students and other aficionados, the author organizes his book into three main themes: 1) music and musical events that express the cultural unity of the country by focusing on national identity. In this group, Murphy listed samba and its role in the carnival, choro, bossa nova, tropicália and MPB, as well as a difficult branch to define, sometimes called "música romântica" (romantic music) or "brega", especially Roberto Carlos; 2) songs that express regional identity - this item encompasses music in capoeira, indigenous music, northeast genres (cavalo marinho, bumba-meu-boi, maracatu, baião), country music and music from the south; 3) music (and audiences) showing cosmopolitanism in genres that can be considered global such as rock, rap and electronic music. This topic, which intends to examine how 
Brazilian musicians make use of international languages, focuses on the music scene from Recife (Pernambuco).

Unquestionably, it is a schematic division targeted to present Brazilian musical diversity in which the author is aware of the limitations of his model. Indeed, he adds that it would be possible to discuss each genre in relation to these three axis, and that perhaps bossa nova would stand out as the most commendable for that possibility, due to that fact that it is Brazilian music, and at the same time is carioca and cosmopolitan. In fact, it seems to be a useful formulation to look at Brazilian popular music. Actually, some genres seem to claim to be national, while others are unabashedly regional. Moreover, some sorts of music incline towards cosmopolitanism, part of which seeks to present a certain indication of Brazilianness, whilst others do not even have such concern.

However, for a book named Music in Brazil - even if found in a series on ethnomusicology, which tends to take traditional and popular music as privileged objects - attention is drawn to the minor fragment dedicated to classical music, one single page squeezed in between the parts dedicated to choro and bossa nova. It seems disproportionate even taking the objectives of the book into consideration. It would have been better to mention in the preface that classical musical production would not be addressed.

BÉHAGUE's Musiques du Brésil, released in 1999, is part of a series in French co-edited by Cité de la Musique and the publisher Acts Sud, which has 23 titles dedicated to various musical cultures. The books which are of medium size, slightly larger and more extensive than a paperback edition, are accompanied by a CD and present the general characteristics of the music culture in focus. As Béhague recognizes, his book is schematic and its dimensions allow only a glimpse of the general characteristics of Brazilian music. In accordance with the objectives of the series, it addresses the traditional and popular music, leaving classical music aside. The introduction situates the country's ethnic and cultural composition and the effect caused on musicality, as well as basic historical and social information given to a non-Brazilian audience. Thenceforward, the book is divided into three chapters devoted to: 1) Luso-Brazilian traditional music; 2) African-Brazilian traditional music; 3) urban popular music. The first two draw attention to traditional Brazilian music genres, separated between those that have a more Portuguese influence opposed to those with more of an African influence. Such divisions generally tend to be controversial. For instance, Béhague classifies congado and bumba-meuboi as having a Luso-Brazilian origin, whereas other authors prefer to consider those as part of the African-Brazilian traditions. The longest chapter focuses on urban popular music and is divided into items in which several genres are discussed.

While Murphy has chosen to group genres according to their relationship with issues of identity, Béhague preferred to separate them between traditional music and urban popular music. However, he has perceived the strong presence of regional characteristics that contribute to form well-defined identities. Nevertheless, despite the existence of regionalisms, the author indicates the existence of common stylistic elements in all repertoires, such as a symmetrical melodic structure, tonal and modal scales, rhythmic treatment and instrumentation (BÉHAGUE, 1999, p.18). Regarding the typical hybridism of Brazilian musical expressions, as a product of multi-ethnic formation, BÉHAGUE provides a useful development, despite the recognition of its limitations as a simplified model that tends to be generalized. 
Ainsi pourrait-on distinguer les dualités extrêmes avec un complexe "plus africain ou plus indien donc moins européen", à l'une des extrémités de l'échelle, et un autre complexe "moins africain ou moins indien donc plus européen", à l'autre extrémité. Tout au long de l'échelle, on peut donc repérer les signes de la nature relative du métissage d'une tradition musicale particulière. (BÉHAGUE, 1999, p.15-16)

Whether, on the one hand, this literature, as a whole, underlines the historical narrative which has samba and the traditional lineage of Brazilian popular music as its axis, on the other, musicians who had repercussions abroad, tend to gain greater prominence in these studies than they received in researches carried out in Brazil. Therefore, some events earned greater prominence than they have in the hegemonic narratives in Brazil, such as the rediscovery of the Mutantes and Tom Zé in the United States, and their international repercussions after that, as well as the recordings of Paul Simon and Michael Jackson with Olodum, or the episode of the international success of lambada and the saga of the song Chorando se foi.

It is interesting how bossa nova is sometimes perceived abroad as a banality of questionable artistic value, by a certain amount of listeners, as a form of muzak or easy listening music for elevators, supermarkets, shopping malls, waiting rooms and airports. This perception only came about due to the great commercial success and ubiquity of the genre. Pointed out by some authors and more clearly formulated by TREECE (2013), such a perception is an apprehension that could only have been thought of in the northern hemisphere, where, in fact, in some countries and environments, the genre has been reformatted to be used as background music, facts which are unlikely to be seen in Brazil. Treece argues that the mediation of American jazz in the international spread of bossa nova led to the transformation of a song gender in an instrumental style, with consequent breakdowns of complex structural relations between the melodic-harmonic intervals, the rhythmic movement as well as the discursive argument and its vocalization. This helped forge the path for the genre to be reformatted and coined as easy listening. Nevertheless, bossa nova continues to arouse interest in other groups of the public and among musicians in particular, even in the new generations. According to STROUD (2008, p.179), the CD So long, by Bebel Gilberto, which presents a review of the tradition of bossa nova, in 2004, became Brazil's greatest commercial success in the international market yet.

Treece also addresses a question of the current view, that Brazil would be an essentially musical culture compared to other cultures, supposedly more literate and literary. That conception would be anchored to the idea that the strength of the country's musical culture is a counterpart of relative poverty and weakness of their linguistic culture. Such an idea would be tuned to the proposition that the high level of music and dance in the African-inspired cultures would be derived from its "orality" and "corporeality", in contrast to the European culture, considered more cerebral and rational. Treece opposes to this idea, stating that language - in religious texts, narratives, songs or improvised verses - plays a central and not a peripheral role in the cultures of the African diaspora. Diametrically opposed to these statements, he holds that Brazilian musicality developed precisely by means of interaction with a rich linguistic inventiveness. These controversial propositions are open to many reflections, and in this regard, it is important to emphasize that the mind/body dichotomy needs to be overcome. The Kantian conception that the aesthetic experience should be disinterested and distant from the body appetites predominates in many theories of art. This criterion is partial and unfavourable for much of the popular music production, especially that of greater sensory appeal. 
In that sense, the reflection about the concepts that privilege certain musical productions at the expense of others, Sean STROUD, in The defence of tradition in Brazilian popular music: politics, culture and the creation of Brazilian popular music (2008), develops a thought-provoking analysis on the formation of the idea of tradition and the concepts of "quality" and "authenticity" in popular music. Two questions are central to his study: 1) how and why did MPB come to boast a high status while representing only a fraction of the country's musical market? 2) Why has the musical tradition in Brazil, of which MPB is an integral part, been defended so vigorously for so long? While dealing with such issues, the author developed a comprehensive research which started from previous studies, especially the works by Enor Paiano and Marcos Napolitano, and which enrolled and incorporated a set of sources and data, which until then had not been given due attention; these include both the state's role as a cultural mediator through the Fundação Nacional de Artes (FUNARTE) and the role of projects like Pixinguinha, Música do Brasil and Rumos Itaú Cultural Música.

Regarding the African heritage in Brazilian music, the book by Peter FRYER ${ }^{11}$ is a fundamental text. It demonstrates how African culture permeated our musicality and was decisive in the formative process of the country's musical culture. In this study, the focus is on the colonial period and the 19th Century, but is extended to the beginning of the 20th Century. FRYER mobilises a consistent set of travellers' accounts around the dancing and music of black people. Such accounts - most, if not all - are known and frequently mentioned in studies on Brazilian music; but do not appear jointly articulated in the study of music in a single text anywhere else. In the absence of the music itself as a source, FRYER relies on documents produced by travellers to evoke the black music that intermittently sounded on the streets of the cities of the 17th to 19th Centuries, especially in Salvador, Recife and Rio de Janeiro. The author substantiates the importance of black culture in the formation of Brazilian musicality without embarking on the complex discussion of the country's ethnic formation and miscegenation or using the jargon enshrined in discussions of this issue. The musical blend between the various pieces of cultural information that coexisted during the period under study arises naturally in FRYER's discourse. In order to emphasise the qualities of black culture, the author has no need to criticise the "whites"; his approach is not committed to the racialised view of culture. On the contrary, it indicates how Brazilians - descendants of Europeans, Africans, Indigenous and mestizos - were absorbing the black musical culture, but modulating it with their own cultural information. According to FRYER (2000, p.137), the acculturation was a two-way street: "African cultural heritage in Brazil played a decisive role in creating a musical culture that is neither African nor Portuguese, but distinctly Brazilian."

The books by Bryan McCANN, Hello, hello Brazil: popular music in the making of modern Brazil (2004), and Marc HERTZMAN, Making samba: a new history of race and music in Brazil (2013),

\footnotetext{
${ }^{11}$ Peter Fryer (1927-2006) was a professional journalist and amateur musician: in his last weeks of life, he played blues on the piano in a Brazilian bar in London. As a journalist, he covered the uprising of Hungary in 1956, crushed by the army of the Soviet dictatorship. He published his account in the book Hungarian Tragedy, in which he defends the Hungarian Revolution, which he considered truly socialist. Therefore, and for his affinity with the Trotskyist movement, he was expelled from the Communist Party of Great Britain. A few days before his death, he was awarded the Knight's Cross, by the Hungarian Order of Merit of the Republic for his "continued support of the Hungarian Revolution and fight for freedom." He wrote about the history of Portugal and history and culture of blacks, among other issues. Having a Brazilian son-in-law, he made several trips to Brazil that contributed to his study of black heritage in Brazilian music.
} 
are among the few works with a historiographical profile and are the only developed in the field of History in these Anglo-American studies.

The book by McCann presents the thesis that, between the late 1920s and mid-1950s, the themes and former practices had been abandoned or radically reinterpreted and at the end of the period, a new set of issues and practices were consolidated and continue to define the cultural life in Brazil. That period approximately coincides with the years of Getulio Vargas' government, as the changes began before 1930, like the Week of Modern Art in 1922, the appearance of choro, the works by Villa-Lobos, and Cannibalistic Manifesto by Oswald de Andrade.

Three elements would bring about cultural changes in the late 1920s: the development of radio, the exchanges between highbrow and lowbrow culture, and the state's role in the process. At the end of the period, a window of opportunities for cultural production would be closed. According to McCann, between 1930 and 1955, the connection between samba and national identity developed in three stages. At first - around 1930-1937 - the circuit of samba accepts and even cherishes the notion that samba represents national identity; different interpretations coexist in that respect. Secondly, around 1937-1945, the field of samba is narrowed and few interpretations of its meaning become acceptable; the dominant line is the vision of samba from the "morro" (the hilltops in the outskirts of Rio de Janeiro) as national essence, pointing towards a racially democratic future. And thirdly, from around 1945 to 1955, a revival of critical samba would come to be. This new trend would analyse the country's problems and in particular, the failure of the so-called "racial democracy". However, the two latter trends have coexisted since then, sometimes within the same composer. In other words, since then, samba has served both to celebrate the nation as to question its flaws. McCann analyses the role of regionalism - in particular, the identification of Luís Gonzaga as a northeasterner and Dorival Caymmi as a "baiano" (understood as a specific identity pertinent to those from the state of Bahia, and in particular from its capital, Salvador). The national repercussions of both composers and performers came to prominence due to radio broadcasting from Rio de Janeiro and its connections with nationalism and debates on national identity in progress at the time.

According to McCann, in contrast to the political scene during those years, and in Estado Novo in particular, the field of popular culture was democratic. Those who were creating a new style of popular music engaged themselves in the cultural market and played a key role in the formation of new cultural expressions, as well as taking part in the debates on national identity, going against the grain of its economic and political marginalization. However, McCann points out that black sambistas would not have been completely compensated for their inventions, since the preference was for white interpreters. If however, on a political level, the struggles for building a national culture were restricted to pro-government intellectuals and politicians, on a cultural level - as a whole and more particularly on a musical level - they were much broader. Among the topics under discussion, the issues regarding foreign influences and the role of the market were of course, relevant. On this fundamental aspect, McCann notes that the title of his book - alluding to Hello, Hello Brazil, a Cinédia movie - indicates his optimistic interpretation of the commercial nature of popular music. About the criticism of the music market, he quotes a passage from Eric Hobsbawm: "Jazz musicians are professionals. Prejudice against 'commercialism' among a large section of the jazz public makes it necessary to repeat this obvious truth" (McCANN, 2004, p.15-16). 
McCann's book is an important contribution to the historiography of popular music in the period it was released, especially the history of samba and music from Rio de Janeiro in general; it is also as a reference for reflection on the discussions about the formation of national identity. However, the author focuses his analysis on the city of Rio de Janeiro, as it was common, until recently, in the historiography of popular music in Brazil. Aware of this limitation, he argues that this was inevitable because Rio was the country's administrative and cultural capital, home of professional recording studios and the most powerful radio stations. From a historical point of view on the relations between music and politics and the debates on the construction of national identity, this "Rio-centrism" appears to be justified; in that sense, the book is consistent with the objectives it proposes. On the other hand, a history of popular music in Brazil requires going beyond it, since - as it is known - a great deal of regional music, which is deemed national in this day and age, was developed in various parts of the country during the same period and rightfully appreciated by their audience.

As an example of the dialogue within this bibliography, HERTZMAN (2013) quotes McCann's book as one of his references, which would pave the way for his work. Hertzman mentions his full agreement with Eric Hobsbawm's passage, quoted by McCann, about the professional character of musical activity, although he pinpoints that such an agreement does not necessarily apply to McCann's optimistic interpretation of the commercial nature of popular music in Brazil. He said that the focus of his book on "African-Brazilian" musicians reflects the central role of these in the creation of samba and development of the music market, but that this centrality should not be understood as a statement that the genre would be coined as "black music". For him, no music can be considered "black", "white" or have any other label of racial connotation; a racialised definition of genres would be as socially constructed and often as misunderstood as the idea of "race". Hertzman states that samba was formatted by multiple groups and individuals, but is often defined as "black" and its complex history is reduced to a narrative of essentialised and simplified backgrounds.

An important revision presented by Hertzman on the historiography of samba is the criticism of a very common narrative that he calls the "punishment paradigm", i.e., the widely accepted idea that samba had been repressed and marginalized with violence before becoming a symbol of national identity. According to him, this narrative was formed between the late 1920s and mid-1940s and is set between the years 1960 and 1970, largely due to the memory project "Depoimentos para a posteridade" (Testimonials for posterity), developed by the Museu da Imagem e do Som do Rio de Janeiro since 1966. Hertzman quotes many researchers who claimed that samba was banned by the authorities in the first decades of its existence, a statement that he peremptorily considers to be incorrect.

As far as Hertzman is concerned, there were different motivations to accept and embrace this paradigm, as well as their interpretations: some would speak about this story of repression of samba as a way to draw attention and denounce racism; others would employ this narrative with the aim of arguing that inequality and racism were a past left behind by a more enlightened and egalitarian society. Hertzman discards some arguments in the first place. According to the author, the Brazilian Penal Code of 1890, which lasted until 1940, does not refer to samba or any other form of musical expression, which implies that the genre was not prohibited by law. Hertzman's questioning to the punishment paradigm is based on a research that involved an 
inquiry on a large collection of police documents including the arrest of musicians and a random sampling of 400 cases of arrests for vagrancy. His conclusion is that the police would be less interested in musicians, and more concerned about other more profitable forms of "vices" like gambling and prostitution. Hertzman adds a sexist aspect to the paradigm, which would contribute as much to prevent women from participating in making and rising the genre, as to minimise a certain violence against women that provoked police interventions, claimed by the offenders to be due to their condition of samba players.

McCann's and Hertzman's books are relevant contributions to the historiography of Brazilian popular music. However, in spite of their merits, they also share a problem located in other titles of the literature under analyses herein: they do not treat the musical aspects of the song. They are texts about music where the music itself is not present. Nevertheless, from a methodological point of view, these studies present a step forward compared to previous researches; e.g., the aforementioned PERRONE's book (1989) or the work of Lisa SHAW, The social history of the Brazilian samba (1999). Both focused very intensely on the analysis of song lyrics, albeit in these cases, it must be considered a fact that they are researchers originally from the field of Languages and Literature (Letras).

In fact, the incorporation of formal elements of music in the historical and sociological studies is a question still not fully resolved - in music studies as a whole and internationally - in which the field of popular music studies in Brazil has presented great progress. In this regard, it can be said that in this bibliography in English, unlike what happens in Brazil, the studies conducted by researchers from the musicological field reached a more balanced interdisciplinary approach - encompassing formal elements, but also considering the context - more so than works coming from the Humanities and Social Sciences, where the music itself is often absent, although there are exceptions, such as the book by David Treece.

\section{7 - Final considerations}

The study of the bibliography gathered herein underscores the importance of Brazilian researches being published in English and other languages. The low level of international projection of our universities, with limited supply of courses in English and other languages, as well as the low proportion of our publications in foreign languages, are aspects that have undermined the evaluation of our institutions in international indicators of scientific quality. Clearly, this is a much bigger issue of which music studies are a small part; and several authors in the musical field are already working in this direction. On the other hand, the affirmation of the importance of publishing our production in English does not line up with a xenophobic and narrow perspective, that foreign researchers are taking advantage of an object of study that would belong to us. These studies of Brazilian music developed abroad are an invaluable contribution to the knowledge of our music; they play the central role of mediating its international dissemination. The perception from abroad of the musical field in Brazil allows for a reflection about this field that is not under pressure of internal symbolic struggles.

By means of this literature, we can expand our dialogue and understanding of cultural concepts that promote the appreciation and attract foreign attention, at least in academic circles, of certain genres of Brazilian popular music over others, including classical production in general. 
We may ask: as the country attracts by means of its musicality, why are our Music colleges and academic production not attractive to other countries in the same way that their production in other areas and even in music is to ours? Are we prepared for an international debate in this field? If not, what are the immediate steps to be taken? If we seek recognition for a musical production according to traditional academic principles, we can also begin to accept that such forums in the northern hemisphere value a sort of musicality that is produced according to other equally valid principles. The search for representativeness of a more erudite production and the growth and dissemination of academic production on popular genres are not mutually exclusionary proposals.

\section{References}

1. AVELAR, Idelber; DUNN, Christopher (eds.) (2011). Brazilian popular music and citizenship. Durhan \& London: Duke University Press.

2. APPLEBY, David P. (1983). The music of Brazil. Austin: University of Texas Press.

3. (2002). Heitor Villa-Lobos: a life (1887-1959). Scarecrow Press.

4. BAIA, Silvano Fernandes (2014). A linhagem samba-bossa-MPB: sobre a construção de um discurso de tradição da música popular brasileira. Per Musi. Belo Horizonte: UFMG, n.29, p.155-169.

5. (2015). A historiografia da música popular no Brasil: análise crítica dos estudos acadêmicos até o final do século XX. Uberlândia: EDUFU.

6. BÉHAGUE, Gerard (1966). Popular musical currents in the art music of the early nationalistic period in Brazil, ca. 1870-1920. PhD dissertation. New Orleans: Tulane University.

7. _ (1968). Biblioteca da Ajuda (Lisbon) MSS 1595-1596: two eighteenth-century anonymous collections of modinhas. Yearbook/Anuário. Inter-American Institute for Musical Research, v.4, p.44-81.

8. _ (1994). Heitor Villa-Lobos: the search for Brazil's musical soul. ILAS Special Publication. Austin: University of Texas Press.

9. ___ (1999). Musiques des Brasil: de la cantoria a la samba-reggae. Arles: Cités de la Musique, Actes Sud.

10. BROWNING, Barbara (1995). Samba: resistance in motion. Bloomington: Indiana University Press.

11. BURDICK, John (2013). The color of sound: race, religion and music in Brazil. New York: New York University Press.

12. CROOK, Larry (2005). Brazilian music: Northeastern traditions and the heartbeat of a modern nation. World Music Series. Santa Barbara: ABS-CLIO. (2nd ed. renamed: Focus: music of Northeast Brazil. New York: Routledge, 2009).

13. DENT, Alexander Sebastian (2009). River of tears: country music, memory and modernity in Brazil. Durham \& London: Duke University Press.

14. DUNN, Christopher (2001). Brutality garden: Tropicália and the emergence of a Brazilian counterculture. Chapel Hill: The University of North Carolina Press.

15. DUNN, Christopher; PERRONE, Charles (2001). Brazilian popular music and globalization. Gainesville: University Press of Florida. 
16. FRYER, Peter (2000). Rhythms of resistance: African musical heritage in Brazil. London: Pluto Press.

17. GALINSKY, Philip (2002). Maracatu atomico: tradition, modernity, and postmodernity in the Mangue movement and the "new music scene" of Recife, Pernambuco, Brazil. New York: Routledge.

18. GALM, Eric (2010). The berimbau: soul of Brazilian music. Jackson: University Press of Missisippi.

19. GARCIA, Thomas; LIVINGTON-ISENHOUR, Tamara (2005). Choro: a social history of a Brazilian popular music. Bloomington: Indiana University Press.

20. GATES, Eunice Joiner (1939). Brazilian music. Hispania. v. 22, n.2, p. 129-134

21. HERSKOVITS, Melville (1946). Drums and drummers in Afro-Brazilian cult fife. The Musical Quarterly. v.30, p.477-492.

22. HERTZMAN, Marc A. (2013) Making samba: a new history of race and music in Brazil. Durham, NC: Duke University Press.

23. HENRY, Clarence Bernard (2008). Let's make some noise: Axé and the African roots of Brazilian popular music. Jackson: University Press of Mississippi.

24. KIEFER, Bruno (1977). História da música brasileira: dos primórdios ao início do século XX. Porto Alegre: Movimento.

25. LEU, Lorraine (2006). Brazilian popular music: Caetano Veloso and the regeneration of tradition. Aldershot \& Burlington: Ashgate Publishing Group.

26. McCANN, Bryan (2004). Hello, hello Brazil: popular music in the making of modern Brazil. Durham \& London: Duke University Press.

27. McGOWAN, Chris; PESSANHA, Ricardo (1991). Billboard book of Brazilian music: samba, bossa nova, and the popular sounds of Brazil. London: Guinness Publishing. Edições seguintes: The Brazilian sound: samba, bossa nova, and the popular music of Brazil. Philadelphia: Temple University Press, 1998.

28. MOEHN, Frederick (2012). Contemporary Carioca: Technologies of Mixing in a Brazilian Music Scene. Durham and London: Duke University Press.

29. MURPHY, John P. (2006). Music in Brazil: experiencing music, expressing culture. Global Music Series. Oxford: Oxford University Press.

30. PARDUE, Derek (2008). Ideologies of marginality in Brazilian hip hop: retelling marginality through music. New York: Palgrave Macmillan.

31. PEPPERCORN, Lisa M. (2005). Villa-Lobos: the music. An analyses of his style. London: Kahn \& Averill Publishers.

32. PERRONE, Charles (1989). Masters of contemporary Brazilian song: MPB 1965-1985. Austin: University of Texas Press.

33. SADIE, Stanley; TYRRELL, John (ed.) (2001). New Grove dictionary of music and musicians. (online version) New York \& Oxford: Oxford University Press.

34. SANDRONI, Carlos (2001). Feitiço decente: transformações no samba no Rio de Janeiro (1917-1933). Rio de Janeiro: Zahar/UFRJ.

35. SHAW, Lisa (1999). The social history of the Brazilian samba. Aldershot \& Brookfield: Ashgate Publishing 
Group.

36. STEVENSON, Robert (1968). Some Portuguese sources for early Brazilian music history. Yearbook/Anuário. v.4, p.1-43.

37. STROUD, Sean (2008). The defence of tradition in Brazilian popular music: politics, culture and the creation of Música Popular Brasileira. Aldershot \& Brookfield: Ashgate Publishing Group.

38. SWANSON, Paul (2015). Domination and resistance in Afro-Brazilian music. Kindle e-book: Amazon Digital Services.

39. TREECE, David (2013). Brazilian jive: from samba to bossa and rap. London: Reaktion Books Ltd.

40. VERHAALEN, Marion (2005). Camargo Guarnieri, Brazilian composer. Bloomington: Indiana University Press.

41. VIANNA, Hermano (1995). 0 mistério do samba. Rio de Janeiro: Zahar.

42. VOLPE, Maria Alice (2010). 0 legado de Gerard Béhague (1937-2005). Revista Brasileira de Música, v. $23 / 1$.

43. WADE, Bonnie C. (2003). Thinking musically: experiencing music, expressing culture. Oxford: Oxford University Press.

44. WRIGHT, Simon (1992). Villa-Lobos. Oxford: Oxford University Press.

Note about the author:

Silvano Baia is a PhD in History from the School of Philosophy, Literature and Human Sciences at the University of São Paulo (2010), M.A. in Music from the Institute of Arts at the São Paulo State University (2005) and Graduate in Music with a major in guitar by the same institution (2001). His post-doctoral research was carried out at the Department of Spanish, Portuguese and Latin American Studies - King's College London (2014/2015). He is currently professor at Institute of Arts at the Federal University of Uberlândia. Author of the book $A$ historiografia da música popular no Brasil: análise crítica dos estudos acadêmicos até o final do século XX (EDUFU, 2015). 